\title{
Carbamazepine-Induced Lymphocytic Interstitial Pneumonitis
}

\author{
Karbamazepine Bağlı Lenfositik Interstisyel Pnömoni
}

Ebru Damadoğlu, ${ }^{1}$ Cüneyt Saltürk, ${ }^{1}$ Ebru Sulu, ${ }^{1}$ Sevda Gökceer, ${ }^{2}$ Huriye Berk Takır, ${ }^{1}$

Leyla Yağcı Tuncer, ${ }^{1}$ Adnan Yılmaz, ${ }^{1}$

\section{Abstract}

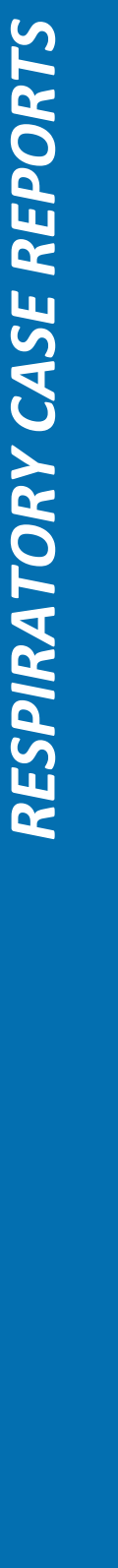

A twenty-seven-year-old male was admitted with cough, sputum production, dyspnea and weight loss. Postero-anterior chest x-ray showed bilateral, diffuse reticulonoduler infiltration. He had received tuberculosis treatment in the past and he had been on carbamazepine for 8 years for a seizure disorder. Three sputum smear examinations for acid-fast bacilli were negative. Pulmonary function tests revealed FVC of $2.35 \mathrm{~L}$ (51\%), FEV1 of $2.12 \mathrm{~L}(54 \%)$, FEV1/FVC of $90 \%$, DLCO of $39 \%$ and DLCO/VA of $75 \%$. Fiberoptic bronchoscopy was normal. Transbronchial lung biopsy and bronchial washing were nondiagnostic. Right minithoracotomy and open lung biopsy were performed. Pathologic examination revealed diagnosis of lymphocytic interstitial pneumonitis. Carbamazepine was withdrawn after neurological consultation. The patient was clinically and functionally well two months later. Computed tomography of the thorax was completely normal. The patient was consideredto be compatible with carbamazepine-induced lymphocytic interstitial pneumonitis.

Key words: carbamazepine, drug-induced, lymphocytic interstitial pneumonitis.

\section{Özet}

Yirmi yedi yaşında erkek hasta öksürük, balgam çıkarma, nefes darlığı ve kilo kaybı yakınmaları ile başvurdu. Arka-ön akciğer grafisi bilatera, yaygın retikülonodüler infiltrasyon gösteriyordu. Hasta geçmişte tüberküloz tanısı ile tedavi almıştı ve epilepsi nedeniyle 8 yıldır karbamazepin kullanıyordu. Üç balgam örneği aside dirençli basil açısindan negatif idi. Solunum fonksiyon testinde FVC 2.35L (\% 51), FEV1 2.12 L (\% 54), FEV1/FVC \% 90, DLCO \% 39 ve DLCO/VA \% 75 bulundu. Fiberoptik bronkoskopi normal idi. Transbronşiyal akciğer biyopsisi ve bronşiyal lavaj tanısal değildi. Sağ mini torakotomi ile açık akciğer biyopsisi yapıldı. Patolojik inceleme lenfositik interstisyel pnömoni olarak bildirildi. Nöroloji konsültasyonu sonrası karbamazepin kesildi. İki ay sonra hasta klinik ve fonksiyonel olarak iyi idi. Toraks bilgisayarlı tomografi normal olarak değerlendirildi. Hasta karbamazepine bağlı lenfositik interstisyel pnömoni olarak kabul edildi.

Anahtar Sözcükler: karbamazepin, ilaca bağll, lenfositik interstisyel pnömoni.

\footnotetext{
${ }^{1}$ Süreyyapaşa Chest Diseases and Thoracic Surgery Training and Investigation Hospital, Departmant of Pulmonology, ${ }^{2}$ Göztepe Training And Invesitigation Hospital, Department of Neurology, İstanbul, Turkey

${ }^{1}$ Süreyyapaşa Göğüs Hastalıkları ve Göğüs Cerrahisi Eğitim ve Araştırma Hastanesi, Göğüs Hastalıkları Kliniği, İstanbul ${ }^{2}$ Göztepe Eğitim ve Araştırma Hastanesi, Nöroloji Kliniği, İstanbul
}

Submitted (Başvuru tarihi): 02.07.2012 Accepted (Kabul tarihi): 20.07.2012

Correspondence (iletişim): Adnan Yılmaz, Süreyyapaşa Chest Diseases and Thoracic Surgery Training and Investigation Hospital, Departmant of Pulmonology, İstanbul, Turkey

e-mail: adnandr_63@yahoo.co.uk 
Drug-induced disease is a fairly common problem in routine medical practice. Interstitial pneumonitis is the most common form of drug-induced pulmonary interstitial disease (1). Carbamazepine is widely used in the treatment of epilepsy, neuropathic pain and bipolar affective disorders (2). A large number of side effects have been reported, including hematological, hepatic, neurological, cardiac, dermatological and renal disorders $(2,3)$. Pulmonary complications have rarely been recognized with carbamazepine (3). We present a case of lymphocytic interstitial pneumonitis induced by carbamazepine.

\section{CASE}

A twenty-seven-year-old male was admitted with cough, sputum production, dyspnea and weight loss. Postero-anterior chest x-ray showed bilateral, diffuse reticulonodular infiltration (Figure 1 ).

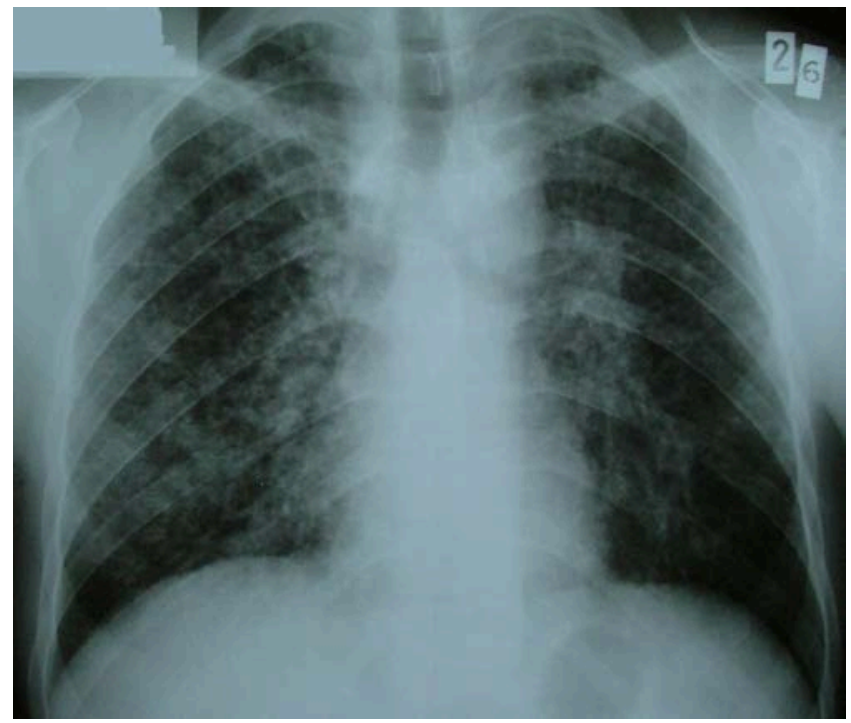

Figure 1. Chest $x$-ray shows bilateral, diffuse reticulonoduler infiltration.

He had received tuberculosis treatment in the past and he had been taking carbamazepine for 8 years for a seizure disorder. The physical examination was normal except for coarse crackles heard in both hemithoraces. Routine laboratory tests were within normal limits. Erythrocyte sedimentation ratio was 30 $\mathrm{mm} /$ hour. Three sputum smear and culture examinations for acid-fast bacilli were negative. Computed tomography of the thorax showed diffuse reticulonodular infiltration and ground glass appearance in both lungs (Figure 2).

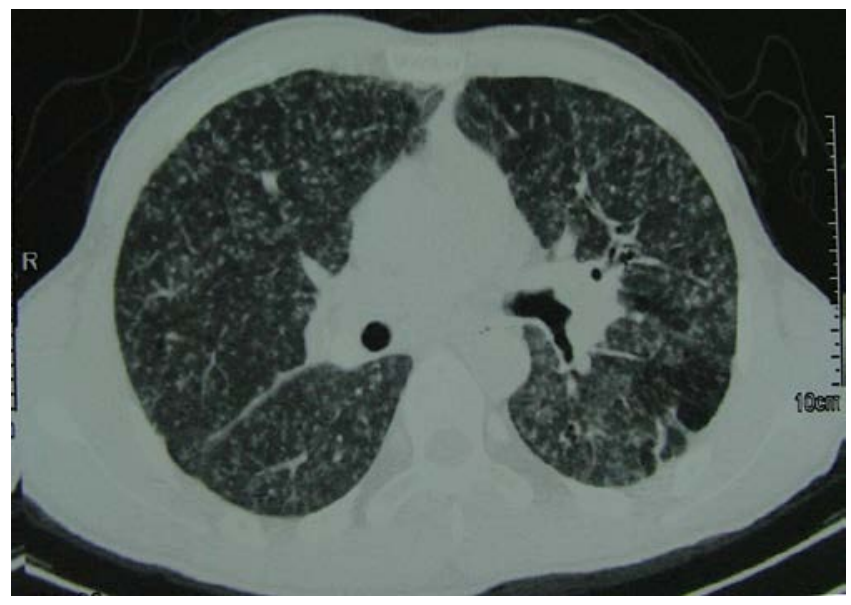

Figure 2. Computed tomography of the thorax shows diffuse reticulonoduler infiltration and ground glass appearance in both lungs

Mediastinal or hilar lymphadenopathy was not observed. Anti-nuclear antibody, anti-DNA antibody, rheumatoid factor and serologic tests for HIV infection were all negative. Fiberoptic bronchoscopy was normal. Transbronchial lung biopsy and bronchial washing were nondiagnostic. Direct examination of bronchial lavage and culture for acid-fast bacilli were negative. Right mini-thoracotomy and open lung biopsy were performed. Pathologic examination revealed diagnosis of lymphocytic interstitial pneumonitis. There was no granuloma in biopsy material. Carbamazepine was withdrawn after neurological consultation. The patient was clinically and functionally well two months later. Computed tomography of the thorax was completely normal (Figure 3).

The patient was considered to be compatible with carbamazepine-induced lymphocytic interstitial pneumonitis.

\section{DISCUSSION}

Lymphocytic interstitial pneumonia (LIP) is a benign lymphoproliferative disorder characterized by a diffuse and exquisitely interstitial proliferation of small lymphocytes and plasma cells (4). LIP occurs most commonly in patients who have Sjögren syndrome, autoimmune thyroid disease, acquired immuno-deficiency syndrome, or Castleman disease $(5,6)$. 


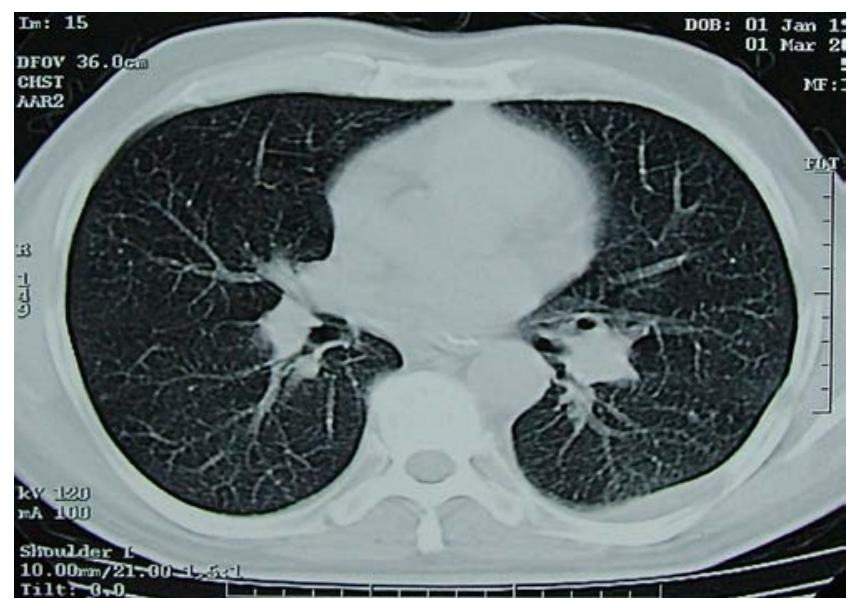

Figure 3. Computed tomography of the thorax was completely normal two months later.

Several drugs such as carbamazepine and diphenylhydantoin can induce interstitial pneumonia (1-3,7-9). Carbamazepine is a commonly used anticonvulsant drug. While carbamazepine-induced pulmonary sideeffects are very uncommon, interstitial pneumonitis, bronchiolitis obliterans organizing pneumonia, bronchospasm, pulmonary oedema and pulmonary nodules have all been reported $(2,3)$. The mechanism of lung injury by carbamazepine was recognized as an immune-mediated hypersensitivity (3). To our knowledge, there have been few cases of carbamazepine-induced interstitial pneumonia in medical literature in English. We present a case of lymphocytic interstitial pneumonitis induced by carbamazepine. Our patient presented all clinical, radiological and functional features of interstitial disease. The diagnosis of LIP was established by open lung biopsy. The withdrawal of carbamazepine was followed by rapid clinical, radiological and functional improvement.

In conclusion, carbamazepine can produce lymphocytic interstitial pneumonitis. Our case points to the importance of the past medical history of patients.

\section{CONFLICTS OF INTEREST}

None declared.

\section{REFERENCES}

1. Deniz Ö, Tozkoparan E, Ilvan A, Çiftçi F, Bozkanat E, Öztürk S. A case of carbamazepine-induced lymphocytic interstitial pneumonitis. Turk J Med Sci 2000; 30:509-10.

2. Archibald N, Yates B, Murphy D, Black F, Lordan J, Dark $J$, et al. Carbamazepine-induced interstitial pneumonitis in a lung transplant patient. Respir Med 2006; 100:1660-2. [CrossRef]

3. Takahashi N, Aizawa H, Takata S, Matsumoto K, Koto $\mathrm{H}_{\text {, }}$ Inoue $\mathrm{H}$, et al. Acute interstitial pneumonitis induced by carbamazepine. Eur Respir J 1993; 6:1409-11.

4. Liebow AA, Carrington CB. Diffuse pulmonary lymphoreticular infiltrations associated with dysproteinemia. Med Clin North Am 1973; 57:809-43.

5. Johkoh T, Ichikado K, Akira M, Honda O, Tomiyama N, Mihara $\mathrm{N}$, et al. Lymphocytic interstitial pneumonia: follow-up CT findings in 14 patients. Thorac. Imaging 2000; 15:162-7. [CrossRef]

6. Johkoh T, Müller NL, Pickford HA, Hartman TE, Ichikado K, Akira $M$, et al. Lymphocytic interstitial pneumonia: thin-section CT findings in 22 patients. Radiology 1999; 212:567-72.

7. King GG, Barnes DJ, Hayes MJ. Carbamazepine-induced pneumonitis. Med J Aust 1994; 160:126-7.

8. Schmidt M, Brugger E. Case of carbamazepine-induced interstitial pneumonia. Med Klin 1980; 75:29-31.

9. Chamberlain DW, Hyland RH, Ross DJ. Diphenylhydantoin-induced lymphocytic interstitial pneumonia. Chest 1986; 90:458-60. [CrossRef] 